\title{
Model for Managing Corporate Social Responsibility
}

UDC: 005.35 ;

005.214

DOI:10.7595/management.fon.2015.0002

\begin{abstract}
As a crossfuncional process in the organization, effective management of corporate social responsibility requires a definition of strategies, programs and an action plan that structures this process from its initiation to the measurement of end effects. Academic literature on the topic of corporate social responsibility is mainly focused on the exploration of the business case for the concept, i.e., the determination of effects of social responsibility on individual aspects of the business. Scientific research so far has shown not to have been committed to formalizing management concept in this domain to a satisfactory extent; it is for this reason that this paper attempts to present one model for managing corporate social responsibility. The model represents a contribution to the theory and business practice of corporate social responsibility, as it offers a strategic framework for systematic planning, implementation and evaluation of socially responsible activities and programs.
\end{abstract}

Keywords: corporate social responsibility, managing social responsibility, model

\section{Introduction}

Corporate social responsibility (CSR) or socially responsible business (SRB) is a business concept that emerged as a response to increased interest and expectations concerning an appropriate and active role of organizations in the society due to the obvious and significant impact of the business, primarily that of large companies, on the quality of life and the development of society as a whole, as well as on increasing public sensitivity to ethical issues (Dahlsrud, 2008; Carroll, 1999). Topics such as sustainable development and the damage done to the human environment, inadequate treatment of employees, providing products or services that bring customers or clients in an awkward position or danger, corporate and marketing communications that mislead consumers and the general public, are becoming a subject of interest not only of the media, but also of the community as a whole. The number of state regulations regarding environmental or social issues is increasing (Dam and Scholtens, 2008). Investors more frequently base their investment decisions not only on financial performance, but also on social sustainability of operations (Mackey et al., 2007). Consumers themselves are becoming increasingly sensitive to the manifestation of social responsibility by organizations whose products or services they use (Mohr et al., 2001). These factors are shaping the modern business environment within which the organization is expected to achieve economic growth and increase competitiveness, but at the same time contribute to the sustainable development of the economy, environment and society (Krstović et al., 2012).The mission of socially responsible organization is to take into account the full scope of its impact on the community and the environment when making any business decisions. This holistic approach to business represents an organization as an equal partner in the community, one that has certain rights and obligations.

Corporate social responsibility is a relatively new concept, which first appears in the business vocabulary, and then in the academic literature, in the early sixties of the last century. One of the first attempts in theoretical conceptualization is attributed to the author Bowen, who held the view that capital owners and managers of the organization should "apply the policy to make decisions or carry out actions that are desirable in terms of meeting the goals of our society." (Bowen, 1953, p. 6). However, the idea that is at the core of the concept of CSR is as old as the first attempts of regulation of the human society. All historical epochs have carried with them particular economic, legal and moral expectations that the society had in relation to the power accumulated in the economic sphere (SMART Collective, 2007). During the 1960s and 1970s, the movement for the protection of human rights, the environment and consumer rights had a substantial impact on increased expectations that the society had in relation to the business. 
Socially responsible actions undoubtedly have a long tradition. However, what separates today's understanding of CSR efforts from the past is the attempt to manage it strategically and to develop the necessary instruments for that purpose. Companies are becoming increasingly aware that they can contribute to the development that is sustainable in the long run, doing business in a way that will ensure economic growth and increase their competitiveness, at the same time taking into account environmental protection and promoting social responsibility, including the interests of its customers. This paper proposes a strategic framework for managing CSR (Vlastelica Bakić, 2012), which was created as a result of extensive literature analysis, authors' experiences in conducting business and social responsibility projects in multinational companies. In this way, the work provides a unique contribution to the theory and business practice of socially responsible business.

\section{Dimensions of socially responsible business}

Corporate social responsibility is defined in many ways in the literature and in practice (Marsden, 2001; McWilliam \& Siegel, 2001; Pinney, 2001; Jones, 1980). Differences in definitions often reflect the author's perspective or the perspective of an organization from which the term and concept are being observed. Specifically, in addition to theoretical, the most common definitions are the ones made by international institutions dealing with some aspect of the promotion, institutionalization, control or measurement of socially responsible business of organizations. A detailed review of the definitions of the concept of corporate social responsibility and the description of the construct is given by the author Vlastelica Bakić (2012).

According to the International Standard ISO 26000 (2010), corporate social responsibility refers to "the responsibility of an organization for the impacts of its decisions and activities on society and the environment, through transparent and ethical behavior, so it contributes to sustainable development, including health and well-being of society; taking into account the expectations of all stakeholders; is in accordance with applicable law and international norms of behavior and is integrated throughout the organization and applied in its relations". Given that authors believe that the definition offered by ISO is the most comprehensive and precise, it will be used for the further consideration in this work.

In business practice, social responsibility is conceptualized and implemented as business policy and longterm programs that are integrated into all business processes and functions of an organization.

It is possible to perform the systematization of basic dimensions, i.e., elements or areas in which social responsibility is applied in a variety of ways (Carroll, 1991; Dahlsrud, 2008; Perakis, 2010). Regardless of the approach that is adopted, it is important that it covers all key aspects of corporate social responsibility, so it can represent an adequate basis for successful application and development in practice. The mission of the company, or the essence of its functioning is in the ffoundation of the concept; based on the core business and the goal of making profits, dimensions of corporate social responsibility are being built (Vlastelica Bakic, 2012):

- Market - responsible behavior on the market includes placing safe and harmless products and services, with adequate price, with respect to the consumer rights, legal and ethical communication of products and services, etc.

- Work environment, respectively human resources - responsibility towards employees includes ensuring safety at work, respect of human rights, equality (gender, racial, national, etc.), investment in employee development, providing additional markets, working environment, natural environment and community benefits for employees, such as recreation, medical examinations and others.

- Living environment - environmental responsibility implies responsibility as regards the usage, preservation and creation of resources, non-infringement of biodiversity, positive impact on the problem of global warming, etc.

- Community - this means responsibility towards society, which is manifested through the elimination of harmful effects of business on the local community, addressing the needs and concerns of the local community, developing a program of investment in the local community (scholarships, financial support, employee volunteering, ...), then philanthropy and humanitarian activities etc. 


\section{Business case of corporate social responsibility}

From a somewhat extreme, but often quoted attitude by a prominent American economist Milton Friedman, published in The New York Times Magazine (1970, p. 32), that "the only social responsibility of business to increase its profits", until the establishment of the so-called non-profit "social enterprises" whose main objective was the improvement of social welfare, there was a wide range of models of corporate social responsibility that companies and organizations can adopt and develop. The specific approach and dynamics for the introduction of social responsibility in business depends on a range of factors related to the business environment and the organization itself. However, most theorists and practitioners in the field agree that the only long-term and sustainable solution is the one used to generate benefits both for the society and for the company, observed over a longer period. Business decisions motivated exclusively by positive effects on society may be unjustified and even harmful for the company, which in the long term may threaten the operations, profitability of core business, jobs of employees in the company, and consequently the whole industry. On the other hand, business philosophy and policy that ignores the needs of the community can be equally harmful to both sides. Therefore, the efforts of the academic and business communities were focused on identifying the positive effects of CSR on business itself, in the literature commonly referred to as "business case of CSR" (business case for CSR).

According to the authors Carroll and Shabana (2010), a unique model or theory of the business case of CSR has not been defined nor proved so far. The scientific approach is based on the research of the impact of certain aspects of CSR on individual business performances and results, based on which the conclusions about the overall concept are made. Zadek (2000) singled out four basic categories used to organize the adoption of CSR: defense of reputation; reduction of operating costs; integration into a broader business strategy and learning, innovation and risk management. Kurucz et. al. (2008) have also systematized the arguments for CSR in the business context into four categories: reduction of costs and risk; managing competitive advantage; improving the reputation and legitimacy of business and creating results that correspond to all parties (win-win outcomes) through synergistic value creation. Other approaches, represented in the literature, focus on identifying and on empirical research into the benefits of CSR for the different stakeholders of the company, which then directly or indirectly affects business and financial results of the company.

The author Weber (2008) has systematized and presented a large amount of scientific research on the topic of links between CSR and business performance, or research of the benefits that companies have following the adoption and development of socially responsible practices. The same author points out that there are five basic categories used to organize the adoption of CSR: a positive impact on corporate image and reputation; a positive impact on recruitment, motivation and retention of employees; a reduction of operating costs; an increase in revenues due to growth in sales and / or market share; a reduction of risks in relation to CSR.

According to the "Framework for the promotion of CSR in Serbia" (Smart Collective, 2007) which presents one of the first studies on the topic of social responsibility in this country, benefits from the introduction of CSR in business are the following: improving company's reputation, increase in productivity, quality and sales; greater loyalty and employee motivation; acceptance in the local community; competitiveness and market positioning.

The research and explanations of business case of CSR in the academic literature are dominated by empirical studies of the link between socially responsible business and financial performance of companies. Margolis and Walsh (2003, p. 273) gave an overview and analysis of 127 empirical studies of the mentioned relations, implemented from 1972 to 2002 . Although there are differences in methodology and indicators of CSR and financial performances, which were used in the studies, the conclusion of the authors above is that the analysis indicates a positive relationship between these two aspects of the business. Orlitzy et al. (2003, p. 403), as well as the Mackey et al. (2007, p. 820) in their research also confirmed a positive correlation between CSR and financial performance. Furthermore, the research done by the Economic Intelligence Unit (EIU) organization, conducted in 2008, states that the vast majority of business leaders in the United States believe that there is a clear correlation between social and financial performances of the company.

Paralell to the increasing prevalence of socially responsible business in practice, but also in academic research, a number of studies conducted in the last few decades have focused on establishing links between corporate social responsibility and consumer reaction, i.e., the perception of CSR and its impact on consumer 
behavior in relation to the goods and services, but also to the company itself (Aguilera et al., 2007; Ellen et al., 2006; Mohr et al., 2001; Sen \& Bhattacharya, 2001). Studies have shown that one of the main reasons why companies adopt and practice social responsibility is the belief of management that consumers expect or even demand a socially responsible approach to business. However, when it comes to the so-called "socially responsible behavior when purchasing", defined as the search for companies and prefering purchase from the socially responsible companies, only a small percentage of consumers fall into "socially responsible consumers." This means that for most consumers corporate social responsibility does not present a significant criterion when deciding to purchase, as the price, quality, proximity of sale and others do.

Based on the literature review and research on the subject, it can be concluded that the academic literature is mainly focused on the exploration of the concept of business justification, or determining the effects of social responsibility on the individual aspects of the business. Research has not been sufficiently focused on defining and structuring the process of management of socially responsible activities and programs from their initiation to the measurement and evaluation of end effects. Therefore, in this paper we propose a model for the management of corporate social responsibility in organizations.

\section{Managing socially responsible business}

Corporate social responsibility, as well as the most business concepts, has been adopted gradually in the managerial practice. The intensity, direction and shape of the evolution of CSR in companies depend on: the specifics of the market in terms of economic, technological and political development and quality, core business and organization size, demographic characteristics and expectations of stakeholders and the general public, as well as other factors. Perakis (2010) believes that the "maturity" of a company in the implementation of the concept of CSR can be on one of five levels: corporate image - CSR is based only on individual philanthropic activities (donations) and is being used as a promotional tool; responsible business operations - introducing a socially responsible practices in the specific domain of business; development expanding the field of application of CSR, through the creation of new business processes or new ways of conducting business processes for greater social responsibility; evolution - change and adapting business models to the demands of social responsibility; revolution - a new business model, initiated exclusively by socially responsible business.

For an effective management of socially responsible business, as a crossfunctional process in the organization, it is necessary to define strategies, programs and action plans. Specific models or guidelines for the management of social responsibility in organizations are to be found in the manuals of international organizations, such as the Global Compact of the United Nations, UNDP or the body of the European Union specializing in corporate social responsibility. According to the authors' opinion, one of the more comprehensive and applicable models is shown in the Handbook for Socially Responsible Business, published by UNDP in Croatia in 2005, based on the publication of the British organization "Business in the Community" (UNDP, 2005). Starting from this model, with some modifications, a model for managing social responsibility is shown below.

Specifics of managing social responsibility in comparison with other management functions and processes within the organization are reflected in the following:

- CSR is a strategic concept and it requires commitment of the management and all employees for its initiation and implementation;

- CSR is a crossfunctional concept and its implementation requires the coordination of various business processes in the organization: legal, financial, manufacturing, sales, quality control, communication, etc;

- Some socially responsible activities are already implemented in the organization before the introduction of the concept, but it is essential to record them, possibly to modify them, systematize and place them in a strategic context.

Regardless of the specifics of managing social responsibility listed above, it requires strategic planning in accordance with the business plan of an organization and it should be treated in the same manner as other key documents of the organization (financial plan, production plan, marketing plan, etc.). A model for managing 
corporate social responsibility has benn developed by Vlastelica Bakic (2012), based on extensive research of scientific and technical literature, and practical experience in conducting CSR in multinational companies. The model includes ten stages or steps in the planning, and these steps are shown below (Figure 1).

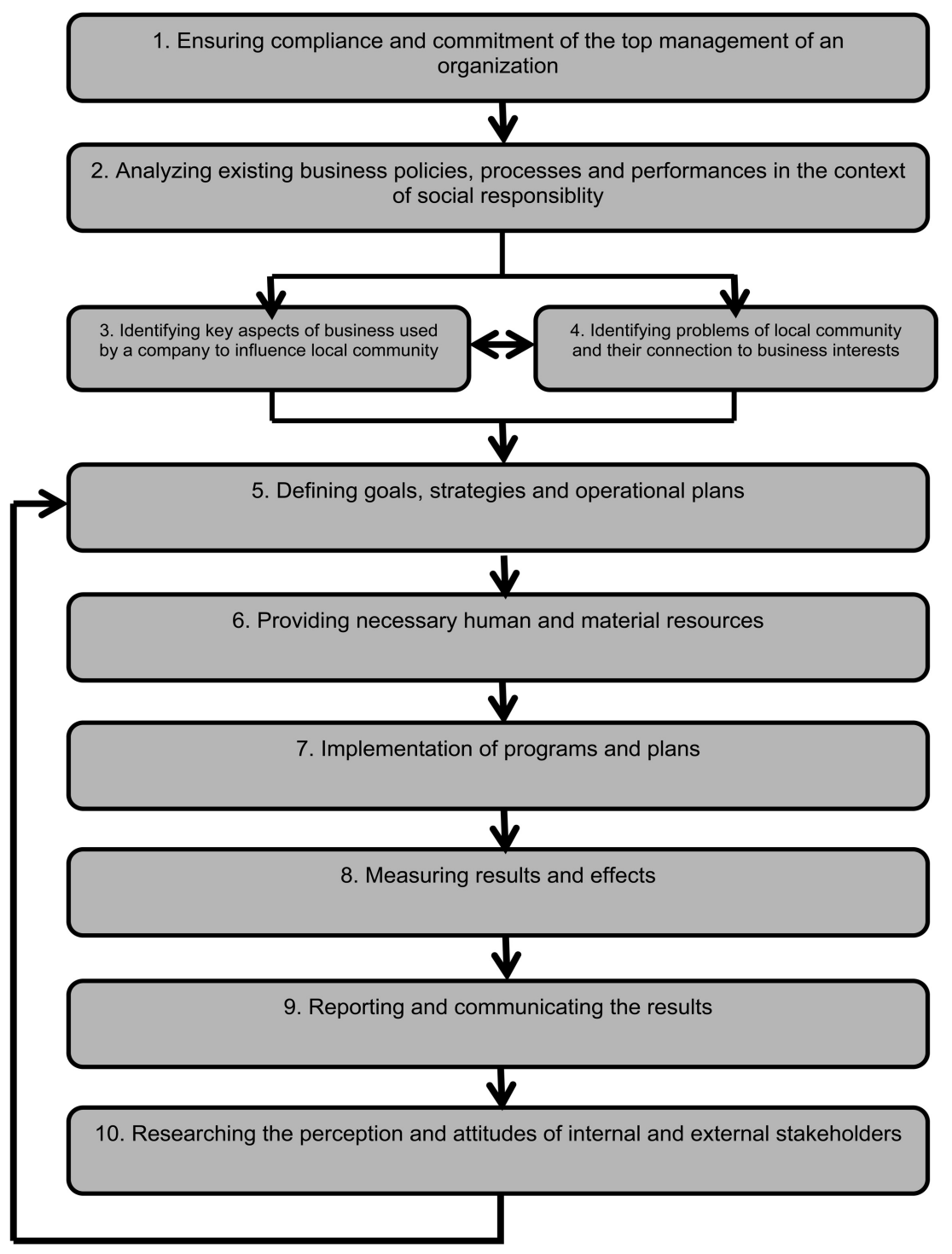

Figure 1: Model for managing corporate social responsibility (Vlastelica Bakić, 2012)

\section{Ensuring compliance and commitment of the top management of an organization.}

The introduction of social responsibility requires a review of the mission, vision and basic corporate values of an organization. As the role of managers in implementing the decisions of the organization (Pechlivanidis \& Katsimpra, 2003) is very important, the agreement and commitment of top management, and in the case of companies the owners, is a necessary first step in this process. As corporate social responsibility is a business philosophy, operationalized through concrete policies and programs, it is prefered that the person responsible for management of social responsibility is high enough in the hierarchy of the organization, in order to have the necessary authority to coordinate crossfunctional processes. Also, for the implementation of specific programs certain human and material resources are essential. Through their assignment in practice the commitment of the top management to the introduction of social responsibility in the organization is manifested. 


\section{Analyzing existing business policies, processes and performances in the context of social responsiblity.}

Although CSR is a relatively new concept, social responsibility is to a greater or lesser extent present in different business processes of organizations (Arjaliès \& Mundy, 2013). Therefore, at the beginning of defining the strategies of CSR, it is recommended that existing documents - policies and processes - should be analysed. Some documents, such as codes of conduct, code of ethics, as well as regulations on occupational safety, are often an integral part of human resources policies and have not been previously treated as documents of CSR. Then, voluntary compliance with certain environmental and other standards in the production process is often an integral part of the business, and adequate improvement and systematization can become part of the social responsibility program. Internal analysis shown above aims to determine the procedures that are missing, and which are necessary to introduce to the organization so it can operate responsibly in relation to its employees, the community and the natural environment.

\section{Identifying key aspects of business used by a company to influence local community.}

One of the basic principles in the strategic management of social responsibility is the so-called "Materiality" which was presented by Perakis (2010). It means that the introduction of corporate responsibility primarily starts from the key aspects of the business with which the organization affects the community. This could be in the area of product, process, or, in the case of providing intellectual services, in the field of employment. For example, if the business is for the most part based on transport, it is first necessary to focus on reducing emissions during transport, and only then on other aspects of CSR, such as scholarships for students in the local community or employee volunteering. When it comes to banks, the primary responsibility is related to the security of financial transactions that customers perform in the bank. If the bank does not communicate transparently, all costs and other aspects of the financial arrangements related to the rights and obligations of clients, each philanthropic action that is initiated may be counterproductive. So, if the company "skips" the introduction of the principle of accountability in its key business processes and in relation to their employees, all efforts in initiating action and other forms of investment activities in the community may be inadequately interpreted and accepted by the stakeholders.

\section{Identifying problems of local community and their connection to business interests.}

The next step in the systematic implementation of social responsibility in business is to identify real problems and needs of the local community in the observed period, to whose settlement or satisfaction an organization can contribute by performing their CSR engagement (Burdge, 2004). Research into these can be performed by desk analysis, i.e., by collecting secondary data at the national or at the local community levels on the topic of: the level of employment, standard of living, the problems of vulnerable groups of society, the state of health care and education, environmental issues and others. In addition to establishing the facts, it is important to determine how important people and important groups of stakeholders feel attached to certain social problems. In this way, the gap that often exists between the expectations of stakeholders regarding the involvement of specific organizations and real performance of these organizations in the areas that stakeholders perceive as important is bein reduced.

\section{Defining goals, strategies and operational plans.}

After detailed analyses are conducted, both internally, in terms of the current situation, capacity of the business plans of the organization, and externally, in the domain of real needs and expectations of the community, it is proceeded to define the appropriate strategies and programs of corporate social responsibility. Van Marrewijk (2003) believes that a successful strategy of social responsibility depends on the specific context of business, and that each company should define how it will establish responsible relationships with its stakeholders and the questions that will be addressed in the framework of its responsibility policies. In this process, the authors believe that they can use two approaches: a) in relation to stakeholder groups (employees, suppliers, customers / consumers, local communities, media) and b) in relation to the dimensions of corporate social responsibility (Basic mission and activities, Work environment, Market, Natural Environment and Community). 
The way of planning and implementation of the concept of social responsibility depends on the size and activities of the organization, social, economic, political and technological specifics of the environment, activities of competitors, identified expectations of stakeholders, available logistics for implementing programs and others. Defining the strategy involves the decision of an organization about the dynamics of implementation of activities, choice of partner organizations, as well as the priorities of individual processes or projects.

\section{Providing necessary human and material resources.}

The introduction of the concept of social responsibility, as well as other business processes, requires the involvement of certain material and human resources. In this regard, an organizational solution, or position in the hierarchy, the number of people in the sector or a team for CSR, as well as clearly defining their powers and responsibilities is extremely significant. Engaging employees whose sole business task is to do so is a positive shift from ad hoc to strategic addressing this issue.

The budget for CSR consists of two parts: one dedicated to the management, coordination of activities and communication, and the other meant for specific costs of implementation of activities. Depending on the person responsible for the implementation of a specific program, the source of the funds is located. As with other management functions (Ehrhart et al., 2007), the budget for CSR can be defined following the "top-down" principle (management determines the total budget for the process, a manager allocates available resources, activities, or cost) or according to the "bottom-up" principle (based on the approved plan, a manager proposes the budget, or the necessary funds for the implementation of the adopted action plan).

\section{Implementation of programs and plans.}

The implementation of social responsibility program in an effective and efficient manner, assuming that the previous steps have been successfully implemented, depends on the involvement and commitment of employees themselves (Lee et al., 2013). Actually, despite the fact that they are expected to carry out certain specific changes and activities, employees are ambassadors of the business philosophy and policies of an organization, and therefore they are the key drivers of social responsibility. It is desirable that the employees are involved in the very process of defining a strategy and specific programs, in order to collect as many quality ideas, and ensure inclusion, and thus higher motivation of staff to implement the program. This can be achieved by adequate internal two-way communication campaign, which allows employees to use various communication tools (suggestion box, intranet, internal magazine, etc.) to express their attitude, idea, suggestion or criticism of a proposal. For example, in a project of corporate volunteering, it is desirable that the employees propose a type of volunteer activity and the institution that they will help.

\section{Measuring results and effects.}

The evaluation of the process and results of corporate social responsibility program starts at the stage of defining objectives. The author Weber (2008) describes the benefits of corporate social responsibility, which she displayed in the "Model of the impact of corporate social responsibility" as qualitative, quantitative, monetary and non-monetary benefits for the company. The model first includes defining key performance indicators for different areas of the benefits of CSR (KPIs), then their quantification and measurement. The author proposes a formula to calculate the monetary added value of CSR (CSR value added) using the method of discounting. The specified value occurs if there has been an increase in income or expenditure reductions by applying the concept of corporate social responsibility.

$$
\text { Monetary added value of } \operatorname{CSR}=\sum_{n=1}^{n=\infty} \mathbf{L}\left(K_{n}^{C S R} \mathbf{】}-T_{n}^{C S R}\right) * \frac{1}{(1+i)^{n}}
$$

where: $n$-period, $K^{C S R}$ - CSR benefits, $T^{C S R}$ - costs of CSR-, $i$ - discount rate. 
There is a whole range of performance indicators used for the evaluation and measurement of CSR. Indicators are defined by the organization itself, taking into account the specifics of the program it adopted and implemented. For this purpose it is possible to use some of internationally recognized methodologies of measurement, such as the London Benchmark Group (LBG Model), Social Return On Investment (SROI), Volunteer Investment and Value Audit (VIVA). In addition to the indicators defined by the organization itself, indicators of external independent institutions specialized in corporate social responsibility can be used. From a number of international organizations dealing with measurement, indexing and ranking companies by these criteria, the following ones stand out: "Corporate Responsibility and Environment Index" (Business organizations in the Community- BITS), "Dow Jones Sustainability Index", "FTSE4Good" and "QLD"index. It is interesting to note that the Reputation Institute, an organization that deals with the global measurement and ranking companies in relation to reputation, introduced the index of corporate social responsibility (Corporate Social Responsibility Index - CSRI) as a derived indicator and a criterion for ranking the company. This index is unique because it is not based on self-assessment or assessment of the performance of companies in the field of social responsibility, but it reflects the public's perception and views on companies in the given area.

\section{Reporting and communicating the results.}

Communicating CSR probably represents the most controversial aspect of this process. In fact, there are different views on whether, how and to what extent is it adequate to communicate the activities and results achieved by the organization in this field (Perks et al., 2013). According to one view, the communication of CSR is a "cheap" market promotion and realization of the benefits of non-market instruments. On the other hand, communicating CSR encourages other organizations to start or intensify their activities in the field of social responsibility and in a certain way creates an extra dimension to compete in business which benefits the society.

\section{Researching the perception and attitudes of internal and external stakeholders.}

In order to obtain feedback on the effectiveness of programs conducted and on defining possible corrective actions for the next cycle, it is necessary to establish a dialogue with key stakeholders. It can be implemented in direct communication, but also through research or surveys. It is extremely important to determine the familiarity of stakeholders and the general public to the activities that have been carried out (whether they heard about the project, how they learn and in how many detailes are they familiar with the organization's efforts in the field of CSR), their assessment of justification, or whether it is to be expected of an organization to engage in a given area and, ultimately, their performance evaluation conducted of the program, project or activity (Costa \& Menichini, 2013). In accordance with the feedback received, it is possible to perform a correction of the future plan of implementation of the concept of corporate social responsibility.

\section{Conclusion}

Corporate social responsibility is one of the important topics in contemporary academic literature in the field of management, marketing and communications, as well as in publications and expert discussion of the business community. CSR as a philosophy is theoretically elaborated and conceptualized; as a business practice it has been accepted and valued. As the theory and practice have proven the effects of CSR on business performance (VlastelicaBakić, 2012; Carroll \& Shabana, 2010, Weber, 2008), there is no doubt that it is necessary to manage corporate social responsibility. This paper presents a model in which the authors provide a strategic framework for managing social responsibility, as a crossfunctional process in the organization, one that structures that process from its initiation to the measurement of end effects. Successful and sustainable management of CSR, which helps achieve long-term benefits for the organization and the society in which it operates, involves an objective, timely and ongoing measurement and assessment of the effects achieved in this area. Therefore, further directions of research in this area necessarily need to focus on defining appropriate evaluation methodologies for the process of corporate social responsibility. For this purpose, it is necessary to make a distinction between measuring process performance (productivity and effectiveness of implementation of a specific project or activity of social responsibility) and measuring the effects that have been made for the organization and society. In the review of the literature it is possible to find numerous approaches to the problems mentioned above, but it is necessary to continue research and conceptualization of this process. 


\section{BIBLIOGRAPHY}

[1] Aguilera, R.V., Rupp, D. E., Williams, C. A. \& Ganapathi, J. (2007). Putting the S back in corporate social responsibility: a multilevel theory of social change in organizations, Academy of Management Review, 32(3), 836-863.

[2] Arjaliès, D.L. \& Mundy, J. (2013).The use of management control systems to manage CSR strategy: A levers of control perspective, Management Accounting Research, 24(4), 284-300.

[3] Bowen, H. R. (1953). Social responsibilities of the businessman. New York: Harper \& Row.

[4] Burdge R. Community needs assessment and public involvement techniques. In: BurdgeR, editor. The concepts, process and methods of Social Impact Assessment.Middleton: Social Ecology Press; 2004a, 223-33.

[5] Carroll, A.B. (1991). The pyramid of corporate social responsibility: toward themoral management of organizational stakeholders. Business Horizons, 34(4), 39-48.

[6] Carroll, A.B. (1999). Corporate social responsibility - evolution of a definitional construction. Business and Society, 38(3), 268-295.

[7] Carroll, A.B.,\& Shabana, K. M. (2010). The Business Case for Corporate Social Responsibility: A Review of Concepts, Research and Practice. International Journal of Management Reviews, 12(1), 85-105.

[8] Costa, R. \&Menichini, T. (2013). A multidimensional approach for CSR assessment: The importance of the stakeholder perception, Expert Systems with Applications, 40(1), 150-161.

[9] Dahlsrud, A. (2008). How Corporate Social Responsibility is Defined: an Analysis of 37 Definitions. Corporate Social Responsibility and Environmental Management, 15(1), 1-13.

[10] Dam, L. \&Scholtens, B. (2008). Environmental regulation and MNEs location: Does CSR matter?, Ecological Economics, 67(1), 55-65.

[11] Ehrhart, K.M., Gardner, R., von Hagen, J. \&Keser, C. (2007). Budget processes: Theory and experimental evidence, Games and Economic Behavior, 59(2), 279-295.

[12] Ellen, P.S., Webb, D.J. \& Mohr, L.A. (2006). „Building corporate associations: Consumer attributions for corporate socially responsible programs, Academy of Marketing Science Journal, 34(2), 147-157.

[13] Friedman, M. (1970). The social responsibility of business is to increase its profits, The New York Times Magazine, 13 September, 32-33.

[14] Krstović, J., Vlastelica Bakić, T., \& Cicvarić Kostić, S. (2012). Uloga biznisa u društvu. Management, 62 , 67-72.

[15] Kurucz, E., Colbert, B. \& Wheeler, D. (2008).The business case for corporate social responsibility In Crane, A., McWilliams, A., Matten, D., Moon, J. \& Siegel, D. (eds), The Oxford Handbook of Corporate Social Responsibility. Oxford: Oxford University Press, 83-112.

[16] Lee, E.M., Park, S.Y., \& Lee, H.J. (2013). Employee perception of CSR activities: Its antecedents and consequences, Journal of Business Research, 66(10), 1716-1724.

[17] Mackey, A., Mackey, T. \& Barney, J. (2007).Corporate social responsibility and firm performance: Investor preferences and corporate strategy, Academy of Management Review, 32(3), 817-835.

[18] Margolis, J.D. \& Walsh, J.P. (2003). Misery loves companies: social initiatives by business, Administrative Science Quarterly, 48(2), 268-305.

[19] Međunarodni standard ISO 26000. Uputstvo o društvenoj odgovornosti. ISO 26000:2010

[20] Mohr, L.A., Webb, D.J. \& Harris, K.E. (2001). Do consumers expect companies to be socially responsible? The impact of corporate socials responsibility on buying behavior, Journal of Consumer Affairs, 35(1), 45-72.

[21] Orlitzy, M., Schmidt, F.L. \& Rynes, S.L. (2003). Corporate social and financial performance: a metaanalysis, Organization Studies, 24(3), 403-441.

[22] Pechlivanidis, P. \&Katsimpra A. (2003). Supervisory leadership and implementationphase, The Leadership \& Organization DevelopmentJournal, 25(2), 201-15.

[23] Perakis, E. (2010). Materijal sa treninga (Training material) "Corporate Social Responsibility", Beograd

[24] Perks, K.J., Farache, F., Shukla, P. \&Berry, A. (2013). Communicating responsibility-practicing irresponsibility in CSR advertisements, Journal of Business Research, 66(10), 1881-1888.

[25] Sen, S. \& Bhattacharya, C.B. (2001).Does doing good always lead to doing better? Consumer reactions to corporate social responsibility, Journal of Marketing Research, 38(2), 225-243.

[26] Smart kolektiv (2007). Okvir za promociju koncepta društveno odgovornog poslovanja u Srbiji

[27] UNDP (2005). Časno do pobjede. Priručnik za društveno odgovorno poslovanje, Zagreb

[28] Van Marrewijk, M. (2003). Concepts and definitions of CSR and corporate sustainability: between agency and communion. Journal of Business Ethics, 44, 95-105. 
[29] Vlastelica Bakić, T. (2012).Upravljanje reputacijom primenom koncepta korporativne društvene odgovornosti u marketingu i odnosima s javnošću, doktorska disertacija, Fakultet organizacionih nauka, Univerzitet u Beogradu, Beograd

[30] Weber, M. (2008). The business case for corporate social responsibility: A company level measurement approach for CSR. European Management Journal, 26(4), 247-261.

[31] Zadek, S. (2000). Doing Good and Doing Well: Making the Business Case for Corporate Citizenship, Research Report 1282-00-RR. New York: The Conference Board

Receieved: September 2014. Accepted: January 2015.

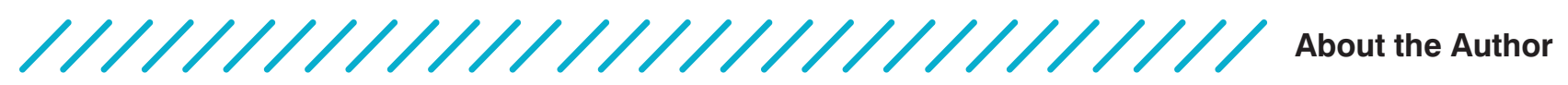

Tamara Vlastelica Bakić

Univeristy of Belgrade, Faculty of Organizational Sciences, Serbia vlastelica.tamara@fon.bg.ac.rs

Tamara Vlastelica Bakić, PhD, is an Assistant Professor at the Department for Marketing and Public Relations, Faculty of Organizational Sciences, University of Belgrade. She is the author of the book "Media Campaign - publicity and advertising" and a co-author of the book "Public Relations Best Practice 2011 and 2013". She is a corporate communications consultant in Victoria Group and was Head of Marketing and Corporate Communications in Deloitte, Corporate Affairs manager and after that a Consultant in Coca-Cola Hellenic, (2007-2011). She was a member of the Managing board of Smart Kolektiv and Public Relations Society of Serbia. Her other responsibilities include a chairperson of the Working Group of United Nations Global Compact for the national CSR strategy. She started her career as a producer of documentaries for foreign TV stations ARD, WDR, Televisione Swizzera-Italiana, etc. Vlastelica Bakić is member of the International Public Relations Association (IPRA), Serbian Association of Managers (SAM), and corporate representative in the American Chamber of Commerce (AmCham), Foreign Investors Council (FIC), Business Leaders Forum (BLF).

\section{Slavica Cicvarić Kostić Univeristy of Belgrade, Faculty of Organizational Sciences, Serbia cicvaric.slavica@fon.bg.ac.rs}

Slavica Cicvarić Kostić, PhD, is an Assistant Professor at the Department of Marketing and Public Relations, Faculty of Organizational Sciences, University of Belgrade. She is the author of books in the fields of branding and communications. She is a Chartered Management Institute approved trainer, level $5 / 7$. Slavica is a lecturer at international studies (joint programmes with Middlesex University London and University of Ljubljana). Her other responsibilities include a consultant in the fields of public relations and marketing for organizations of corporate and public sectors. She worked as a Director of Business Development in the international consulting company for communications, Hauska \& Partner International Communications. She was a Public Relations Manager in the MPC Properties investment company, which was a strategic partner of Merrill Lynch. She is a member of the European Marketing Academy EMAC, International Advisory Council for the Marketing Profession, Council of the Public Relations Society of Serbia, and a member of professional jury for annual public relations awards, as well as marketing communications awards.
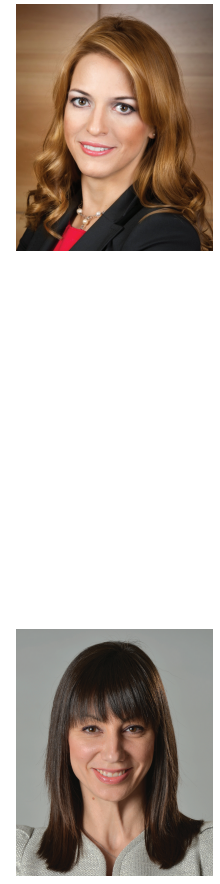

Ema Nešković

Univeristy of Belgrade, Faculty of Organizational Sciences, Jove llića 154 neskovic.ema@fon.bg.ac.rs

Ema Nešković, MSc, is an Assistant Lecturer at at the Department for Marketing and Public Relations at the Faculty of Organizational Sciences, University of Belgrade. She got her bachelor's degree from the Faculty of Organizational Sciences in 2010 and completed her master studies in 2013. Prior to that, she was a member of the winning team at Hult Global Case Challenge 2011, Balkan Case Challenge 2009, and many other case study competitions.

Ema is currently involved in preparing students for global case competitions. She was the holder of Ministry of education grant, Republic foundation for the development of scientific and artistic youth grant and Dositeja grant for best students in Serbia."

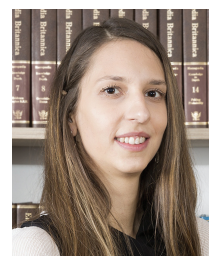

